\title{
PARATE EXECUTIE PADA HAK TANGGUNGAN SEBAGAI PERLINDUNGAN ASET KREDITOR DAN DEBITOR
}

\author{
Oleh
}

\author{
Yusuf Arif Utomo*
}

\begin{abstract}
Abstrak
Bank dalam memberikan pinjaman kepada calon debitor biasanya selalu meminta jaminan tambahan yang dapat berupa barang bergerak ataupun barang tidak bergerak. Untuk jaminan barang tidak bergerak dapat berupa rumah dan/atau tanah. Dalam perjalanannya diperlukan peraturan yang detail untuk melindungi kepentingan para pihak. Hal ini dapat berupa parate executie pada jaminan debitor yang diberikan kepada kreditor (bank).
\end{abstract}

Keyword : debitor, kreditor, parate executie

\section{Pendahuluan}

Pembangunan ekonomi, sebagai bagian dari pembangunan nasional, merupakan salah satu upaya untuk mewujudkan kesejahteraan rakyat yang adil dan makmur berdasarkan Pancasila dan Undang-Undang Dasar $1945^{1}$. Kegiatan pembangunan ekonomi sudah tentu membutuhkan dana yang tidak sedikit. Bagi masyarakat, guna meningkatkan kebutuhannya baik konsumtif maupun produktif, seringkali membutuhkan dana segar dalam jumlah besar, dalam arti dana yang besar dibutuhkan oleh masyarakat dalam bentuk tunai. Masyarakat selain butuh dana dalam bentuk tunai juga menginginkan dapat segera mendapatkan dana tersebut agar bisa lebih cepat untuk

\footnotetext{
* Bank Jatim, yusuf24 arif21@yahoo.com Tanggungan
}

digunakan dalam pengembangan usahanya. Salah satu lembaga keuangan yang dapat dijadikan sumber pendanaan bagi masyarakat yang utama adalah bank, karena sesuai dengan fungsinya, bank sebagai wadah penyalur dana dalam bentuk kredit bagi pengembangan usaha guna membantu program pengembangan perekonomian bangsa. Pelayanan Bank guna memenuhi kebutuhan masyarakat mengenai dana kredit sangat besar dan juga akan terus meningkat mengikuti perkembangan ekonomi nasional maupun global. Dana kredit yang diberikan Bank kepada para debitornya bukanlah dana pribadi Bank, melainkan dana masyarakat luas, sedangkan dana pribadi Bank atau dana yang berasal dari para pemegang saham bank jumlahnya relatif kecil dibandingkan kebutuhan kredit masyarakat yang harus 
dilayani Bank itu sendiri. Oleh karena itu, maka dalam pemberian kredit oleh bank kepada masyarakat (perorangan ataupun badan usaha) harus ada perlindungan hukum bagi masing-masing pihak. Perlindungan hukum tersebut dapat melalui lembaga hak jaminan yang kuat agar dapat memberikan kepastian hukum bagi semua pihak yang berkepentingan sebagai upaya mengantisipasi timbulnya resiko bagi kreditor pada masa yang akan datang ${ }^{2}$.

Dalam penyaluran dana kredit yang dilakukan oleh pihak bank kepada para debitornya pada umumnya selalu disertai dengan adanya jaminan kebendaan yang nantinya akan menjadi Obyek Jaminan. Apabila dalam perjanjian kredit tersebut tidak disertai dengan adanya jaminan kebendaan, maka kedudukan bank yang memberi kredit selaku kreditor akan sama dengan kreditor-kreditor yang lain, ini berarti masing-masing kreditor termasuk kreditor pemberi kredit (Bank) akan mendapatkan hak yang berimbang dari hasil penjualan harta kekayaan debitor, apabila debitor cedera janji. Kedudukan yang berimbang antara sesama kreditor inilah yang tidak memberikan kepastian kepada kreditor pemberi kredit (Bank) akan terjaminnya pengembalian piutangnya.

Jaminan kebendaan tersebut didalam perjanjiankredityangdilakukanbanksebagai kreditor dengan debitornya biasanya disebut sebagai agunan. Dalam pasal 1 angka 23 Undang-Undang No. 10 tahun 1998 tentang

\footnotetext{
${ }^{2}$ Herowati Poesoko, parate executie Obyek Hak Tanggungan (Inkonsistensi, Konflik Norma dan Kesesatan Penalaran dalam UUHT, LaksBang PRESindo, Yogyakarta, 2007, hal. 2.
}

Perbankan, yang menyebutkan bahwa agunan adalah jaminan tambahan yang diserahkan Nasabah Debitor kepada Bank dalam rangka pemberian fasilitas kredit atau pembiayaan berdasarkan prinsip syariah. Melihat ketentuan tersebut maka dapat disimpulkan bahwa dalam perjanjian kredit antara kreditor (bank) dengan debitornya disertai dengan jaminan tambahan yakni berupa jaminan kebendaan.

Berbeda apabila perjanjian kredit tersebut disertai dengan adanya jaminan kebendaan, karena dengan adanya jaminan tersebut selain membuat posisi kreditor menjadi kreditor Preverent, juga sebagai bentuk upaya perlindungan hukum bagi kreditor $^{3}$. Apabila debitor wanprestasi maka kreditor dapat melaksanakan eksekusi atas obyek jaminan milik debitor. Dalam pelaksanaannya tentu saja melalui beberapa cara, dapat melalui prosedur penyitaan terlebih dahulu seperti yang diatur dalam Kitab Undang-Undang Hukum Acara Perdata ataukah dengan cara tanpa melalui prosedur penyitaan terlebih dahulu ${ }^{4}$. Namun cara mana yang mungkin oleh kreditor lebih mudah dan dapat segera mendapatkan pelunasan utangnya kembali.

Selain bertujuan memberikan perlindungan aset kepada kreditor, Jaminan Kebendaan tersebut juga harus mampu memberikan perlindungan aset terhadap harta Debitor. Agar harta debitor

\footnotetext{
${ }^{3}$ Sutan Remy Sjahdeni, Hak Tanggungan AsasAsas, Ketentuan Pokok, dan Masalah yang Dihadapi Oleh Perbankan, Alumni, Bandung, 1999, hal. 10.

${ }^{4}$ J. Satrio, Hukum Jaminan Hak Jaminan Kebendaan, Citra Aditya Bakti, Bandung, cetakan ke 5, 2007, hal. 255. (selanjutnya disebut J. Satrio I)
} 
yang dijadikan jaminan tidak dieksekusi sembarangan, namun perlu memperhatikan harga jual barang yang ada di pasaran dan nilai dari fasilitas kredit yang diberikan.

Memang Obyek Jaminan Kebendaan sangat beragam, namun seringkali Jaminan Kebendaan yang dimaksud dalam upaya penyaluran dana kredit oleh kreditor (dalam hal ini Bank selaku kreditor pemberi kredit) berupajaminanatastanah. SehinggaLembaga Jaminan yang digunakan adalah Lembaga Jaminan Hipotik dan creditverband $^{5}$. Pada awalnya pengaturan mengenai hipotik diatur dalam pasal 1162-1232 Burgelijk Wetboek (selanjutnya disingkat B.W.), sedangkan untuk credtiverband diatur dalam Staatsblaad tahun 1908 Nomor 542 yang diubah dengan Stb. 1937-190. Namun setelah lahirnya Undang-Undang No. 5 tahun 1960 tentang Peraturan Dasar PokokPokok Agraria (selanjutnya disebut UUPA) terutama pada pasal 51, maka menjadikan sebuah kerangka baru pembuat UndangUndang untuk merumuskan secara khusus pengaturan mengenai Jaminan Kebendaan berupa tanah yang baru terealisasi pada tahun 1996 melalui Undang-Undang No. 4 tahun 1996 tentang Hak Tanggungan Atas Tanah Beserta Benda-Benda yang Berkaitan DenganTanah (selanjutnyadisingkatUUHT) yang menjadikan peraturan sebelumnya yang mengatur Hipotik dan creditverband menjadi tidak berlaku. Namun pada pasal 26 UUHT menyatakan bahwa eksekusi hipotik yang masih ada sejak berlakunya UUHT ini masih tetap berlaku terhadap eksekusi Hak Tanggungan sepanjang belum

\footnotetext{
5 Herowati Poesoko, Op.Cit, hal. 3.
}

ada pengaturan dalam perundang-undangan yang mengaturnya.

Namun seiring dengan perkembangan ekonomi bangsa dan perubahan pada pola pikir bangsa, maka seringkali kemudahan yang diberikan oleh UUHT mengenai eksekusi Obyek Hak Tanggungan justru memberikan efek yang negatif terhadap debitur, karena pada dasarnya pengaturan mengenai eksekusi Obyek Hak Tanggungan dalam UUHT haruslah tidak merugikan semua pihak yang terkait dalam perjanjian Kredit dengan Jaminan tersebut. Seringkali malah kreditur berharap debitornya wanprestasi atau debitor tidak sanggup melunasi hutangnya, sebab dengan demikian kreditor dapat melakukan eksekusi secara mudah, bahkan seringkali dalam pelaksanaan penjualan Obyek Hak Tanggungan akibat debitor wanprestasi terjadi permainan harga jual dipasaran oleh kreditor dengan calon pembeli barang Obyek Hak Tanggungan. Hal tersebut tentunya dangat merugikan debitor, bahkan seringkali teradi shock therapy yang dilakukan oleh kreditor terhadap debitor agar mau melepas barang yang dibebani Hak Tanggungan agar dapat segera dieksekusi tanpa melalui proses sebagaimana mestinya yang ditentukan dalam UUHT. Hal tersebut tentunya sudah sangat melewati batas dan sangat merugikan debitor, karena seharusnya debitor mendapat harga jual Obyek Hak Tanggungan sesuai dengan harga pasar yakni sesuai dengan Nilai Jual Obyek Pajak (NJOP) dan mendapatkan sisa uang hasil penjualan Obyek Hak Tanggungan setelah dikurangi pelunasan utangnya kepada kreditor. 
Berdasarkan uraian diatas sangat penting kiranya permasalahan tersebut ditelaah lebih lanjut guna menemukan solusi atau pemecahan terhadap persoalan tersebut. Serta diharapkan dapat menimbulkan kesadaran yang tinggi pada masyarakat luas yang ingin mengajukan kredit dengan disertai Hak Tanggungan agar tidak terlalu merasa tertekan apabila berhadapan dengan kreditor selaku pemberi kredit dan pemegang Hak Tanggungan yang menyalah gunakan hak istimewa yang diberikan UUHT. Tentunya dapat menjadi pijakan bagi masyarakat untuk menyelesaikan kasuskasus yang berhubungan dengan eksekusi terhadap Obyek Hak Tanggungan.

Berdasarkan pembahasan diatas maka pokok permasalahan yang akan Penulis kemukakan adalah bagaimana kewenangan kreditor selaku pemegang Hak Tanggungan dalam melakukan parate executie yang diberikan oleh Undang-Undang No. 4 tahun 1996 (UUHT) dan bagaimana bentuk perlindungan hukum bagi kreditor pemegang Hak Tanggungan dan debitor selaku pemberi Hak Tanggungan dalam eksekusi dengan cara parate executie yang diberikan oleh UUHT.

\section{Parate Executie}

Eksekusi merupakan sebuah upaya paksa yang dilakukan oleh kreditor apabila dalam pemenuhan prestasi oleh debitor, ternyata debitor cedera janji atau wanprestasi. Eksekusi diatur dalam H.I.R. atau Hukum Acara Perdata, dimana menurut pasal 195 H.I.R. memberikan pengertian tentang eksekusi adalah menjalankan putusan hakim oleh pengadilan. Syarat utama dalam suatu eksekusi harus memiliki "titel" yang didalamnya terkandung hak seseorang yang harus dilaksanakan, maka sesuai dengan istilah sehari-hari "putusan hakim" itulah yang dilaksanakan sehingga disebut eksekusi. Titel tersebut sama dengan putusan hakim karena diawal akta otentik berbunyi "Demi Keadilan Berdasarkan Ketuhanan Yang Maha Esa", inilah yang menimbulkan pendapat bahwa eksekusi berarti melaksanakan putusan hakim oleh pengadilan. titel eksekusi demikian biasanya ada dalam grosse acte. Meskipun grosse acte memiliki titel eksekutorial, namun tetap dalam pelaksanaannya harus mendapatkan fiat dari pengadilan. Namun eksekusi tidak hanya melalui titel eksekutorial (putusan pengadilan dan grosse acte) saja, ada eksekusi yang tidak mendasarkan pada titel eksekutorial, yakni penjualan dibawah tangan dan parate executie. Dalam bidang Hukum Jaminan, eksekusi Obyek Jaminan adalah pelaksanaan hak kreditor pemegang Hak Jaminan terhadap Obyek Jaminan, apabila debitor cedera janji ${ }^{7}$. Eksekusi terhadap Obyek Jaminan ini diatur dalam B.W. pasal 224 H.I.R. Akan tetapi pengaturan mengenai eksekusi Obyek Jaminan ini tidak hanya diatur dalam H.I.R. melainkan juga diatur secara khusus, dimana kreditor diberi hak secara khusus berupa hak menjual atas kekuasaan sendiri apabila debitor cidera janji.

Berbicara mengenai eksekusi pada lembaga jaminan, apabila debitor cedera

\footnotetext{
6 Herowati Poesoko, Op.Cit, hal. 127.

7 Ibid, hal. 128.
} 
janji, maka tidak bisa lepas dari parate executie. Pada dasarnya yang di namakan parate executie menurut bahasa adalah eksekusi langsung ${ }^{8}$, secara ilmiah arti dari parate executie adalah hak untuk menjual atas kekuasaan sendiri Obyek yang dijadikan Jaminan dalam suatu perjanjian hutang piutang apabila si debitor wanprestasi ${ }^{9}$. Dalam B.W. sebenarnya sudah diatur mengenai parate executie. Dalam B.W. ada beberapa pasal yang mengatur mengenai parate executie, karena pada dasarnya parate executie diperuntukkan bagi perjanjian hutang-piutang yang memiliki suatu jaminan tertentu yang membuat kedudukan kreditor menjadi kreditor preverent dimana haknya lebih didahulukan dibandingkan dengan kreditor tanpa diikuti Jaminan Kebendaan. Pada lembaga gadai parate excutie diatur dalam pasal 1155 B.W. yang menyatakan sebagai berikut:

"Apabila oleh para pihak tidak telah diperjanjikan lain, maka si berpiutang adalah berhak, kalau si berhutang atau si pemberi gadai bercidera janji, setelah tenggangwaktuyang ditentukanlampau, atau jika telah tidak ditentukan suatu tenggang waktu, setelah dilakukannya suatu peringatan untuk membayar, menyuruh menjual barangnya gadai di muka umum menurut kebiasaankebiasaan setempat serta syarat-syarat yang lazim berlaku dengan maksud

\footnotetext{
${ }^{8}$ Sri Soedewi Masjchoen Sofwan, Hukum Jaminan di Indonesia Pokok-Pokok Hukum Jaminan dan Jaminan Perorangan, Liberty Offset, Yogyakarta, hal. 32.

9 J. Satrio, Hukum Jaminan Hak-Hak Kebendaan, Citra Aditya Bakti, Bandung, 1986, hal. 61. (selanjutnya disebut J. Satrio II)
}

untuk mengambil pelunasan jumlah piutangnya beserta bunga dan biaya dari pendapatan penjualan tersebut."

Dari pasal 1155 B.W. menunjukkan bahwa ketentuan tersebut dapat disimpangi sepanjang para pihak menentukan lain atau memperjanjikan lain. Ketentuan tersebut masih dapat disimpangi sepanjang para pihak menghendaki, karena ketentuan tersebut bersifat mengatur (anvullend). Namun apabila para pihak tidak memperjanjikan lain, hak tersebut lahir demi hukum ${ }^{10}$, jadi tidak perlu diperjanjikan sebelumnya karena hak tersebut diberikan oleh Undang-Undang. Dalam pasal tersebut juga disebutkan tentang klausula menjual di muka umum. Penjualan tersebut tidak harus disertai dengan adanya titel eksekutorial, dalam hal ini pemegang gadai dapat melakukan penjualan meskipun tanpa melalui penetapan pengadilan ataupun tanpa melalui juru sita. Oleh karena itu pemegang gadai disini menjual atas kekuasaan sendiri, inilah yang disebut parate executie, maka seakan-akan hak eksekusi selalu siap - paraat - ditangan pemegang gadai ${ }^{11}$

Dalam hal jaminan tersebut melalui lembaga hipotik, maka B.W. pun sudah mengatur mengenai parate executie tersebut, yaitu melalui pasal 1178 ayat (2) yang menyatakan bahwa:

"namun diperkenankanlah kepada si berpiutang hipotik pertama untuk, pada waktu diberikannya hipotik, dengan tegas minta diperjanjikan bahwa, jika uang pokok tidak dilunasi

\footnotetext{
10 J. Satrio I, Op.Cit, hal. 121.

11 Ibid, hal. 122.
} 
semestinya, atau jika bunga yang terutang tidak dibayar, ia secara mutlak akan dikuasakan menjual persil yang diperikatkan dimuka umum, untuk mengambil pelunasan uang pokok, maupun bunga serta biaya, dari pendapatan penjualan itu. Janji tersebut harus dilakukan menurut cara sebagaimana diatur dalam pasal 1211."

Dari pasal tersebut ada klausula yang menyatakan tentang kuasa menjual, yang sampai saat ini masih menimbulkan berbagai macam polemik, karena dengan adanya kuasa menjual tersebut dimana pelaksanaannya tidak perlu lagi melalui pengadilan maupun juru sita. Keadaan demikian membuat pelaksanaan eksekusi jadi lebih cepat dan jauh lebih sederhana. Oleh karena itu hak kreditur yang diatur dalam pasal 1178 ayat (2) B.W. dapat disebut sebagai eksekusi yang disederhanakan ${ }^{12}$.

Dalam redaksional pada pasal 1178 ayat (2) B.W. berbeda dengan redaksional pasal 6 UUHT, dimana dalam pasal 6 UUHT menyatakan bahwa:

"Apabila debitor cidera janji, pemegang hak tanggungan pertama mempunyai hak untuk menjual obyek hak tanggungan atas kekuasaan sendiri melalui pelelangan umum serta mengambil pelunasan piutangnya dari hasil penjualan tersebut."

Dalam pasal 6 UUHT juga secara nyata tidak disebutkan adanya hak melakukan parate executie yang diberikan oleh

\footnotetext{
12 Ibid, hal. 248.
}

UUHT kepada debitor, namun dalam pasal tersebut ada klausula yang menyebutkan "menjual atas kekuasaan sendiri" dan ini adalah parate executie. Dalam pasal 1178 ayat (2) hak untuk menjual atas kekuasaan sendiri atau parate executie lahir karena diperjanjikan, namun berbeda dalam pasal 6 UUHT yang menyatakan bahwa hak untuk menjual atas kekuasaan sendiri bukan lahir karena diperjanjikan namun diberikan ex lage, sehingga semua permasalahan parate executie yang timbul karena sifat-sifat/ciriciri kuasa tidak akan muncul kembali dalam $\mathrm{UUHT}^{13}$.

Dari penjabaran pasal-pasal tersebut, maka ada perbedaan yang sangat mendasar mengenai pelaksaaan parate executie dalam lembaga jaminan gadai dan lembaga jaminan hak tanggungan dengan lembaga jaminan hipotik. Dalam lembaga jaminan gadai maupun lembaga jaminan hak tanggungan lahir bukan lagi harus di perjanjikan sebelumnya, namun lahir karena Undang-Undang. Dengan demikian apabila para pihak tidak memerjanjikan mengenai parate executie dalam klausula perjanjian pokok maupun perjanjian ikutan, maka dengan sendirinya kreditor diberi hak untuk melakukan parate executie. Berbeda dengan parate executie dalam lembaga jaminan hipotik, dimana klausula mengenai "menjual atas kekuasaan sendiri" atau parate executie harus diperjanjikan terlebih dahulu. Janji tersebut harus tercantum dalam akte notaris dan didaftarkan terlebih dahulu baru kemudian mempunyai sifat Hak

\footnotetext{
13 Ibid, hal. 308
} 
Kebendaan ${ }^{14}$.

Dari berbagai macam pengaturan mengenai parate executie, maka sebenarnya tujuan dari pengaturan mengenai parate executie adalah agar kreditor mendapatkan kepastian mengenai pelunasan hutangnya daridebitor, selainitujuga guna mempercepat proses pelunasan piutang kreditor manakala debitor wanprestasi dengan cara memberikan hak kepada kreditor untuk menjual Obyek Hak Jaminan atas kekuasaan sendiri melalui pelelangan umum, yang dilaksanakan oleh Kantor Lelang Negara yang dikenal dengan nama KP2LN ${ }^{15}$.

Parate executie dianggap sebagai percepatan pelunasan piutang kreditor, karena sebenarnya hak untuk menjual atas kekuasaan sendiri berarti kreditor pemegang Hak Jaminan dalam melaksanakan hak eksekusinya tidak membutuhkan titel eksekutorial dan dapat melaksanakan eksekusi sendiri secara langsung tidak peduli adanya kepailitan dari debitor (diluar kepailitan) karena kreditor bersifat sparatis $^{16}$.

Memang parate executie memberikan banyak keuntungan bagi kreditor pemegang hak jaminan, namun bukan berarti dengan keuntungan-keuntungan yang diberikan parate executie tersebut dalam pelaksanaannya tidak membutuhkan syarat tertentu. Ada syarat utama yang harus dipenuhi sebelum kreditor pemegang Hak Jaminan melakukan eksekusi menggunakan parate executie, yakni harus ada wanprestasi

\footnotetext{
${ }^{14}$ Sri Soedewi Masjchoen Sofwan, Op.Cit, hal. 32.

${ }^{15}$ Herowati Poesoko, Op.Cit, hal. 240.

${ }^{16}$ Sri Soedewi Masjchoen Sofwan, Op.Cit, hal. 33.
}

dari debitor. Hak untuk menjual atas kekuasaan sendiri atau parate executie baru muncul apabila debitor telah wanprestasi atau debitor telah melakukan cedera janji terhadap pelunasan hutangnya kepada kreditor.

\section{Parate Executie menurut UUHT}

Hak Tanggungan sebagai suatu jenis lembaga hukum, pasti akan mempunyai hubungan dengan lembaga-lembaga lainnya, misalkan dalam hal kepemilikan, eksekusi, peralihan hak, ataupun dengan lembaga jaminan terhadap benda bukan $\operatorname{tanah}^{17}$. Adanya hubungan antara Lembaga Hukum Hak Tanggungan dengan lembaga hukum yang lain merupakan hal yang tidak bisa ditolak, karena pada dasarnya Lembaga Hukum Hak Tanggungan merupakan bagian dari sistem hukum yang saling berkaitan dengan lembaga-lembaga hukum lainnya.

Hak Tanggungan merupakan lembaga jaminan terhadap benda berupa tanah, karena Lembaga Hak Tanggungan tersebut berfungsi sebagai penjaminannya. Dalam suatu perjanjian kredit dalam masyarakat pada saat ini, banyak sekali terjadi hal yang berpotensi menimbulkan kerugian bagi kreditor maupun debitor. Salah satu hal yang sering terjadi didalam suatu perjanjian kredit adalah terjadinya wanprestasi atau cidera janji yang dilakukan oleh debitor, maka guna mengantisipasi hal tersebut diperlukan adanya sebuah lembaga yang bisa memberikan jaminan kepada kreditor maupun debitor untuk merasa aman dalam

${ }^{17}$ Moch.Isneni, "Kerancuan Hak Tanggungan", Amarta, Vol. 1, zzNo. 1, Mei-Agustus 1999, hal. 77. 
memenuhi prestasi dalam perjanjian yang dibuat. Salah satu caranya adalah dengan membuat suatu perjanjian kredit yang diikuti dengan perjanjian jaminan sebagai perjanjian tambahan. Hal tersebut tentunya akan memberikan rasa aman kepada kreditor guna keperluan penjaminan akan pengembalian kreditnya oleh debitor, tentunya jaminan tersebut diwujudkan pada jaminan kebendaan. Adapun dasar hukum yang menyebutkan bahwa Perjanjian Hak Tanggungan adalah perjanjian tambahan atau bersifat accessoir adalah berdasarkan pasal 10 ayat (1) UUHT jo. pasal 18 ayat (1) UUHT yang menyatakan bahwa pemberian Hak Tanggungan merupakan hal yang tak terpisahkan dari perjanjian utang-piutang. Dalam penjelasan pasal 8 UUHT juga menerangkan bahwa Perjanjian Hak Tanggungan merupakan perjanjian accessoir atau ikutan ${ }^{18}$.

Di dalam UUHT memberikan perlindungan atau memberikan hak istimewa kepada kreditor untuk melakukan parate executie. Dalam UUHT pasal 6 yang mengatakan bahwa:

"Apabila debitor cidera janji, pemegang hak tanggungan pertama mempunyai hak untuk menjual obyek hak tanggungan atas kekuasaan sendiri melalui pelelangan umum serta mengambil pelunasan piutangnya dari hasil penjualan tersebut."

Dalam pasal 6 UUHT ternyata memberikan hak istimewa kepada kreditor untuk menjual Obyek Hak Tanggungan

18 Sutan Remy Sjahdeni, Op. Cit, hal. 28. atau benda yang dibebani Hak Tanggungan apabila ternyata dalam proses pemenuhan pestasinya si debitor melakukan wanprestasi atau cedera janji. Hak istimewa yang diberikan oleh UUHT kepada kreditor ini berupa hak untuk menjual atas kekuasaan sendiri benda yang dibebani Hak Tanggungan atau Obyek Hak Tanggungan apabila debitor wanprestasi. Apabila debitor wanprestasi, maka berdasarkan pasal 6 UUHT, pihak kreditor atas kewenangannya dapat menjual sendiri benda jaminan lewat pelelangan umum ${ }^{19}$.

Apabila dilihat secara sederhana memang pasal 6 UUHT memberikan hak untuk menjual sendiri benda jaminan atau dengan kata lain pasal 6 UUHT secara eksplisit memberikan hak untuk melakukan parate executie kepada kreditor apabila debitorwanprestasi, artinyabahwapemegang Hak Tanggungan atau kreditor pemegang Hak Tanggungan tidak perlu bukan saja memperoleh persetujuan dari pemberi Hak Tanggungan, tetapi juga tidak perlu meminta penetapan pengadilan ${ }^{20}$, karena Sertifikat Hak Tanggungan mempunyai kekuatan yang sama dengan penetapan pengadilan. hal ini mengesankan seolah-olah parate executie ini lahir karena undang-undang dan tidak perlu lagi diperjanjikan oleh para pihak dalam hal ini kreditor dan debitor. Dalam pasal 14 ayat (2) UUHT mengatakan bahwa sertifikat Hak Tanggungan memuat irahirah dengan kata-kata "DEMI KEADILAN BERDASARKAN KETUHANAN YANG MAHA ESA", dengan demikian semakin

19 Moch.Isneni, Op. Cit, hal. 85.

20 Sutan Remy Sjahdeni, Op. Cit, hal. 46. 
menguatkan anggapan bahwa Sertifikat Hipotik mempunyai kekuatan hukum yang sama dengan penetapan pengadilan. Berarti parate executie tersebut menurut pasal 6 UUHT lahir karena undang-undang (ex lege).

Namun hal tersebut menjadi sangat rancu dan sangat membingungkan ketika membaca penjelasan pasal 6 UUHT, karena dalam penjelasan pasal 6 UUHT menerangkan bahwa:

"Hak untuk menjual obyek Hak Tanggungan atas kekuasaan sendiri merupakan salah satu perwujudan dari kedudukan diutamakan yang dipunyai oleh pemegang Hak Tanggungan atau pemegang Hak Tanggungan pertama dalam hal terdapat lebih dari satu pemegang Hak Tanggungan. Hak tersebut didasarkan pada janji yang diberikan oleh pemberi Hak Tanggungan bahwa apabila debitor cederajanji,pemegangHakTanggungan berhak untuk menjual obyek Hak Tanggungan melalui pelelangan umum tanpa memerlukan persetujuan lagi dari pemberi Hak Tanggungan dan selanjutnya mengambil pelunasan piutangnya dari hasil penjualan itu lebih dahulu dari pada kreditor-kreditor yang lain."

Dalam penjelasan pasal 6 UUHT setidaknya memberikan dua pemahaman, pertama, hak kreditor untuk menjual atas kekuasaan sendiri didasarkan pada janji apabila debitor wanprestasi atau cidera janji, kedua, hak untuk menjual obyek
Hak Tanggungan atas kekuasaan sendiri merupakan salah satu perwujudan dari kedudukan diutamakan yang dipunyai oleh Pemegang Hak Tanggungan ${ }^{21}$.

Dari pemahaman yang pertama dapat diketahui bahwa ternyata janji untuk menjual atas kekuasaan sendiri harus lebih dahulu diperjanjikan atara para pihak. Dengan demikian parate executie baru ada setelah diperjanjikan terlebih dahulu oleh para pihak. Hal tersebut tentunya sangat bertolak belakang ketika dihadapkan pada pemahaman pasal 6 UUHT sendiri, dimana pasal 6 UUHT mengatakan bahwa hak untuk menjual atas kekuasaan sendiri lahir karena undang-undang (ex lege). Hal tersebut tentunya mencerminkan bahwa sebenarnya UUHT tidak konsisten dalam mengatur mengenai parate executie ${ }^{22}$. Ternyata pengaturan mengenai hak menjual atas kekuasaan sendiri tidak hanya diatur dalam pasal 6 UUHT. Dalam pasal 11 ayat (2) huruf e UUHT juga menerangkan bahwa ternyata hak untuk menjual atas kekuasaan sendiri tersebut juga harus dicantumkan dalan perjanjian Hak Tanggungan. Sebenarnya pasal 11 ayat (2) huruf e UUHT tersebut tidak perlu diadakan, karena wewenang itu telah diberikan oleh UUHT melalui pasal 6, walaupun tidak diperjanjikan wewenang itu sudah ada $^{23}$. Pengaturan yang berlebihan tersebut tentu saja akan mengundang silang pendapat yang melelahkan ${ }^{24}$.

Oleh karena itu berdasarkan pada

${ }^{21}$ Herowati Poesoko, Op.Cit, hal. 250.

22 Ibid, hal. 251

23 Mariam Darus Badrulzaman, Buku II Kompilasi Hukum Jaminan, Mandar Maju, Bandung, 2004, hal. 43.

${ }^{24}$ Moch.Isneni, Op. Cit, hal. 86. 
Undang-Undang No. 10 tahun 2004 tentang pembentukan peraturan perundangundangan dalam lampirannya menyebutkan bahwa penjelasan tidak dapat digunakan sebagai dasar hukum. Selain itu dalam penyusunan penjelasan tidak diperkenakan bertentangan dengan materi pokok yang ada pada batang tubuh dan tidak menguangi uraian kata, istilah, atau pengertian yang telah dimuat dalam ketentuan umum.

Apabila melihat pengaturan dalam lampiran Undang-Undang No. 10 tahun 2004 tentang pembentukan peraturan perundang-undangan, maka kerancuan atau silang pendapat antara pasal 6 UUHT dengan penjelasan pasal 6 UUHT semakin menjadi jelas ketika dikaitkan dengan pasal 11 ayat 2 huruf (e) UUHT, yakni dalam akta pemberian Hak Tanggungan dapat dicantumkan janji-janji yang antara lain adalah janji bahwa pemegang Hak Tanggungan pertama mempunyai hak yang didahulukan untuk menjual atas kekuasaan sendiri obyek Hak Tanggungan dari pada pemegang Hak Tanggungan kedua dan seterusnya, apabila ternyata debitor cedera janji atau wanprestasi. Dengan kata lain penjelasan pasal 6 UUHT tidak mempunyai kekuatan berlaku yang mengikat, sehingga dengan mendasarkan pada alasan tersebut jelas hak kreditor pemegang Hak Tanggungan pertama untuk menjual obyek Hak Tanggungan adalah atas dasar undang-undang (ex lege) bukan atas dasar diperjanjikan ${ }^{25}$.

Pemahaman yang kedua dari penjelasan pasal 6 UUHT adalah mengenai kedudukan yang diutamakan yang dipunyai pemegang HakTanggungan.Padapasal6UUHTternyata juga telah mencampur adukkan antara parate executie dengan kedudukan kreditor preferent sebagai kreditor yang diutamakan karena memiliki Hak Tanggungan. Didalam UUHT memang tidak dijelaskan apa yang dimaksud dengan "kedudukan yang diutamakan", namun berpijak pada pasal 1 ayat (1) UUHT, dapat di tarik kesimpulan bahwa yang dimaksud dengan "kedudukan yang diutamakan" sama dengan "kedudukan sebagai kreditor preferent". Namun perlu diingat bahwa parate executie merupakan perwujudan dari kedudukan kreditor yang memperjanjikan hak jaminan khusus, yaitu memberikan kemudahan kepada kreditor dalam mengambil pelunasan, karena parate executie merupakan prinsip eksekusi yang menyimpang dari eksekusi yang diatur dalam hukum perdata. Jadi parate executie bukanlah perwujudan dari kreditor preferent ${ }^{26}$.

Maka dapat ditarik garis bahwa kerancuan yang ditimbulkan dari penjelasan pasal 6 UUHT sedikit banyak telah membuat bingung para kreditor pemegang Hak Tanggungan, terutama bagi kreditor pemegang Hak Tanggungan pertama. Hal ini disebabkan karena meskipun pada dasarnya lahirnya parate executie dapat diperjanjikan, namun harus ada pemahaman yang tegas yang diberikan undang-undang agar tidak menimbulkan pemahaman yang rancu dalam mekanisme undang-undang itu sendiri yang nantinya bisa menyebabkan penafsiran yang berbeda dan akibatnya

26 Ibid, hal. 257.

\footnotetext{
25 Herowati Poesoko, Op. Cit, hal. 253.
} 
tujuan awal dibentuknya pengaturan pengenai pasal 6 UUHT jadi terlupakan.

Kewenangan dan Prosedur Kreditor dalam Melakukan Parate Executie dalam UUHT

Dalam hal kewenangan kreditor sebagai pemegang Hak Tanggungan dalam melakukan parate executie sesuai dengan UUHT sebenarnya merupakan cara lain yang diberikan oleh UUHT kepada kreditor pemegang Hak Tanggungan guna mendapatkan pelunasannya. Namun sebelumnya telah dibahas mengenai parate executie menurut UUHT, selanjutnya akan diulas mengenai kewenangan kreditor dalam melakukan ataupun menjalankan parate executie sebagai pemegang Hak Tanggungan. Berdasarkan pembahasan sebelumnya, dijelaskan bahwa dasar kreditor dalam melaksanakan parate executie adalah Pasal 6 UUHT, namun ternyata Pasal 6 UUHT sebagai dasar parate executie tidaklah berdiri sendiri, ada beberapa peraturan ataupun ketentuan lain yang berkaitan dengan materi pokok yang terdapat dalam Pasal 6 UUHT sebagai dasar parate executie.

Di dalam UUHT terdapat ketentuan yang mengatur mengenai pelaksanaan eksekusi secara tersendiri. Memang pada dasarnya Pasal 6 sebagai dasar kuat dari kreditor pemegang Hak Tanggungan guna melakukan eksekusi dibawah tangan untuk pendapatkan pelunasan hutangnya, akan tetapi dalam pasal 20 ayat (1) UUHT yang mengatur mengenai Eksekusi Hak Tanggungan menjelaskan bahwa menjual obyek Hak Tanggungan atas kekuasaan sendiri atau parate executie dapat dilaksanakan dengan cara menjual Obyek Hak Tanggungan melalui pelelangan umum. Hal tersebut dijelaskan pada penjelasan Pasal 20 ayat (1) UUHT, dimana pada prinsipnya setiap eksekusi haruslah melalui pelelangan umum, karena diharapkan melalui pelelangan umum tersebut didapatkan harga yang paling tidak atau setidaknya didapatkan harga yang sesuai dengan nilai Obyek Hak Tanggungan tersebut dipasaran. Akan tetapi dalam Pasal 20 ayat (2) jo. Ayat (3) UUHT mencoba membuka peluang bagi kreditor pemegang Hak Tanggungan untuk menyimpangi ketentuan yang adal dalam Pasal 20 ayat (1) UUHT tersebut. Dalam Pasal 20 ayat (2) jo. Ayat (3) UUHT menjelaskan bahwa kreditor pemegang Hak Tanggungan dapat melakukan eksekusi tanpa melalui pelelangan umum, melainkan melalui penjualan dibawah tangan sepanjang para pihak pemberi dan pemegang Hak Tanggungan menyepakatinya, dengan harapan bawa melalui penjualan dibawah tangan tersebut akan dapat diperoleh harga tertinggi yang dapat menguntungkan semua pihak.

Dengan mendasarkan pada ketentuan tersebut, maka hak yang diberikan kepada kreditor pemegang Hak Tanggungan untuk menjual atas kekuasaan sendiri atau parate executie yang didasarkan pada Pasal 6 UUHT tidak harus didasarkan pada adanya suatu perjanjian kuasa.

Apabila dilihat secara sederhana, memang apa yang diberikan oleh UUHT dalam hal menjual Obyek Hak Tanggungan 
atas dasarkekuasaan sendiri(parate executie) adalah bertujuan untuk memberikan kemudahan bagi kreditor pemegang Hak Tanggungan dalam melaksanakan parate executie apabila debitor wanprestasi. Hal tersebut dikarenakan apabila debitor wanprestasi, maka kreditor selaku pemegang Hak Tanggungan dapat melakukan parate executie yang didasarkan pada Pasal 6 UUHT jo. Pasal 20 UUHT. Cara tersebut dinilai jauh lebih mudah jika dibandingkan eksekusi melalui pengadilan. karena apabila menggunakan parate executie yang didasarkan Pasal 6 UUHT tidak diperlukan adanya perjanjian kuasa menjual lagi dan juga tidak perlu menunggu putusan pengadilan, karena seperti yang diulas pada pembahasan sebelumnya mengenai sertifikat Hak Tanggungan dimana terdapat irah-irah "DEMI KEADILAN BERDASARKAN KETUHANAN YANG MAHA ESA". Sehingga dengan adanya irah-irah tersebut, berdasarkan Pasal 14 ayat (3) UUHT yang menyatakan bahwa sertifikat Hak Tanggungan tersebut mempunyai kekuatan untuk melaksanakan eksekutorial yang sama dengan putusan pengadilan yang telah mempunyai kekuatan hukum tetap.

Hal tersebut berbeda apabila mencermati Pasal 1178 ayat (2) B.W. yang menyatakan bahwa:

"namun diperkenankanlah kepada si berpiutang hipotikpertama untuk, pada waktu diberikannya hipotik, dengan tegas meminta diperjanjikan bahwa, jika uang pokok tidak dilunasi semestnya, atau jika bunga yang terutang tidak dibayar, ia secara mutlak akan dikuasakan menjual persil yang diperikatkan dimuka umum, untuk mengambil pelunasan uang pokok, maupun bunga serta biaya, dari pendapatan penjualan itu. Janji tersebut harus dilakukan menurut cara sebagaimana diatur dalam Pasal 1211."

Melihat ketentuan tersebut maka kuasa untuk menjual yang diberikan oleh pemberi hipotik kepada penerima atau pemegang hipotik haruslah didasarkan dengan adanya kuasa mutlak. Dengan demikian apa yang ada dalam Pasal 1178 ayat (2) B.W. tersebut sejalan dengan penjelasan Pasal 6 UUHT yang menjelaskan bahwa;

"Hak untuk menjual obyek Hak Tanggungan atas kekuasaan sendiri merupakan salah satu perwujudan dari kedudukan diutamakan yang dipunyai oleh pemegang Hak Tanggungan atau pemegang Hak Tanggungan pertama dalam hal terdapat lebih dari satu pemegang Hak Tanggungan. Hak tersebut didasarkan pada janji yang diberikan oleh pemberi Hak Tanggungan bahwa apabila debitor cederajanji,pemegangHakTanggungan berhak untuk menjual obyek Hak Tanggungan melalui pelelangan umum tanpa memerlukan persetujuan lagi dari pemberi Hak Tanggungan dan selanjutnya mengambil pelunasan piutangnya dari hasil penjualan itu lebih dahulu dari pada kreditor-kreditor yang lain."

Akan tetapi hal tersebut sangat 
kontradiktif atau bertentangan dengan Pasal 6 UUHT sendiri, karena secara tidak langsung penjelasan Pasal 6 UUHT mengatakan bahwa pemberian kuasa menjual pada Pasal 6 harus didasarkan pada kesepakatan yang dibuat oleh kreditor pemegang Hak Tanggungan dengan debitor pemberi Hak Tanggungan, bukan didasarkan pada kewenangan yang diberikan oleh UUHT. Namun seperti apa yang telah diulas sebelumnya, berdasarkan ketentuan dalam Undang-Undang No. 10 tahun 2004 tentang pembentukan peraturan perundangundangan dalam lampirannya menyebutkan bahwa penjelasan tidak dapat digunakan sebagai dasar hukum. Selain itu dalam penyusunan penjelasan tidak diperkenakan bertentangan dengan materi pokok yang ada pada batang tubuh dan tidak menguangi uraian kata, istilah, atau pengertian yang telah dimuat dalam ketentuan umum, maka yang akan digunakan sebagai dasar hukum kreditor pemegang Hak Tanggungan apabila ingin menggunakan fasilitas untuk melaksanakan eksekusi dalam bentuk parate executie seperti yang disediakan oleh UUHT, adalah pasal 6 UUHT jo pasal 20 UUHT.

Namun demikian persoalan kreditor pemegang Hak Tanggungan dalam melaksanakan parate executie yang didasarkan pada Pasal 6 UUHT bukan berarti berakhir. Pada Pasal 1178 ayat (2) B.W. tidaklah sepenuhnya bertentangan dengan pasal 6 UUHT, hal ini bisa dijelaskan dengan mencermati lebih jauh ketentuan Pasal 6 UUHT yakni:

"Apabila debitor cidera janji, pemegang hak tanggungan pertama mempunyai hak untuk menjual obyek hak tanggungan atas kekuasaan sendiri melalui pelelangan umum serta mengambil pelunasan piutangnya dari hasil penjualan tersebut."

Prosedur pelaksanaan parate executie dalam Pasal 1178 ayat (2) B.W. tidak jauh berbeda dengan Pasal 6 UUHT, yakni dalam melaksanakan parate executie melalui pelelangan umum, dimana berarti logika hukumnya pejabat tersebut adalah Pejabat Kantor Lelang Negara. Oleh karenanya tidak memerlukan fiat Ketua Pengadilan Negeri ${ }^{27}$.

Permasalahan yang muncul selanjutnya apabila dicermati kembali ketentuan pada Penjelasan Umum angka 9 jo. penjelasan Pasal 14 ayat (2) dan (3) UUHT, yang ada intinya menyatakan bahwa prosedur pelaksanaan parate executie harus mendasarkan ada Pasal 224 H.I.R., sehingga dalam pelaksanaannya harus mendapatkan fiat dari Ketua Pengadilan Negeri dimana Obyek Hak Tanggungan berada.

Pada Penjelasan Umum angka 9 UUHT menerangkan bahwa:

"salah satu ciri Hak Tanggungan yang kuat adalah mudah dan pasti dalam melaksanakan eksekusinya, jika debitor cidera janji. Walaupun secara umum ketentuan tentang eksekusi telah diatur dalam Hukum Acara Perdata yang berlaku, dipandang perlu untuk memasukkan secara khusus ketentuan tentang eksekusi Hak Tanggungan dalam undang-undang ini, yaitu yang

\footnotetext{
27 Ibid, hal. 259.
} 
mengatur lembaga parate executie sebagaimana dimaksud Pasal 224 Reglemen Indonesia yang Diperbaharui (Het Herziene Inlands Reglement) dan Pasal 258 Reglemen Acara Hukum Untuk Daerah Luar Jawa dan Madura (Reglement tot Regeling ven her Rechtwezen in de Gewestern Buiten Java en Madura)."

Sedangkan penjelasan Pasal 14 ayat (2) dan (3) UUHT yang menyatakan bahwa:

"irah-irah yang dicantumkan pada sertifikat Hak Tanggungan dimaksudkan untuk menegaskan adanya kekuatan eksekutorial pada sertifikatHak Tanggungan, sehingga jika debitor cidera janji, maka sertifikat Hak Tanggungan dieksekusi seperti halnya putusan pengadilan yang telah memperoleh kekuatan hukum tetap, melalui tata cara dan dengan menggunakan lembaga parate executie sesuai hukum acara perdata"

Melihat ketentuan tersebut dapat ditafsirkan bahwa cara yang digunakan kreditor pemegang Hak Tanggungan dalam menggunakan parate executie disamakan dengan prosedur eksekusi pada sertifikat Hak Tanggungan, yakni dengan menggunakan prosedur sesuai dengan Hukum Acara Perdata yang harus melalui ijin dan atas perintah Ketua Pengadilan Negeri, sesuai dengan pasan 224 H.I.R./Pasal 258 R.Bg. ${ }^{28}$.

Dari penjelasan tersebut dapat dicermati bahwa apabila parate executie harus mendapat fiat dari Ketua Pengadilan Negeri, maka salah satu faktor atau tujuan utama

28 Ibid, hal. 262.
UUHT dalam mengatur mengenai parate executie melalui Pasal 6 UUHT tidaklah tercapai. Hal ini dikarenakan tujuan utama UUHT mengatur mengenai parate executie adalah untuk memudahkan pelaksanaan eksekusi bagi kreditor pemegang Hak Tanggungan apabila debitor pemberi Hak Tanggungan, hal ini tidak terwujud apabila pelaksanaan parate executie harus mendapatkan fiat Ketua Pengadilan Negeri. Namun hal ini tidak seharusnya menjadi polemik tersendiri, karena pesan dari H.I.R/R.Bg. tersebut pada intinya memberikan kemudahan bagi kreditor dalam melakukan eksekusi menggunakan parate executie adalah dalam hal mendapatkan penetapan pengadilan. Hal tersebut dijamin oleh H.I.R/R.Bg. bahwa bagi setiap kreditor pemegang Hak Tanggungan apabila debitor pemberi Hak Tanggungan cidera janji, maka kreditor akan diberikan kemudahan dalam memperoleh penetapan pengadilan apabila akan mengeksekusi obyek Hak Tanggungan dengan cara parate executie. Sehingga kreditor dapat melakukan eksekusi melalui balai lelang sesuai dengan pasal 20 UUHT.

\section{Perlindungan Hukum Bagi Kreditor Pemegang Hak Tanggungan}

Pertumbuhan pembangunan bangsa Indonesia saat ini sangat bergantung pada pertumbuhan ekonomi bangsa Indonesia sendiri. Saat ini banyak sekali usaha-usaha kecil, menengah, maupun usaha tingkat atas yang tumbuh secara cepat di Indonesia. Hal tersebut menimbulkan suatu arus perekonomian baru terkait masalah modal dan pendanaan. Demi mengembangkan 
lebih jauh lagi perekonomian bangsa, saat ini banyak sekali lembaga-lembaga ataupun badan usaha penyalur dana dalam bentuk kredit. Didalam masyarakat saat ini lembaga yang menyalurkan kredit guna membantu pengembangan usaha terutama bagi usaha kecil dan menengah adalah bank.

Sesuai dengan peran dan fungsi bank salah satunya adalah sebagai lembaga yang menyalurkan kredit bagi masyarakat kecil dan menengah untuk pengembangan usahanya. Dalam hal ini peran bank tidak bisa dianggap remeh, melihat kebutuhan masyarakat mengenai pemenuhan kredit sangat besar. Namun tidak hanya bank yang saat ini bergerak dibidang penyaluran kredit usaha bagi masyarakat. Ada lembagalembaga atau badan hukum lain yang memang digunakan sebagai sarana mencari keuntungan selain menyalurkan pinjaman dalam bentuk kredit kepada masyarakat yang memerlukan. Peran lembaga atau badan hukum tersebut juga tidak bisa dipandang sebelah mata. Banyak kalangan pengusaha baik kecil maupun menengah yang sangat bergantung terhadap jasa para penyalur dana kredit tersebut.

Dalam menyalurkan kredit tersebut tentunya didasari dengan adanya suatu perjanjian kredit atau perjanjian hutangpiutang. Perjanjian tersebut bertujuan sebagai upaya atau bentuk perlindungan hukum bagi para kreditor. Perjanjian kredit tersebut juga tidak serta merta berupa perjanjian hutang-piutang, namun harus ada sebuah jaminan yang diberikan oleh debitor kebada kreditor terhadap jaminan pelunasan piutang tersebut. Dalam hal jaminan tersebut berupa tanah maka sesuai dengan UUHT, lembaga yang digunakan adalah Lembaga Jaminan Hak Tanggungan.

Lebih jauh mengarah pada bentuk perlindungan hukum kepada kreditor pemegang Hak Tanggungan ini sebenarnya berupa perlindungan aset kreditor pemegang Hak Tanggungan sebagai upaya guna mendapatkan pelunasan piutangnya dari debitor pemberi Hak Tanggungan.

Apabila seorang debitor selaku pemberi Hak Tanggungan melakukan wanprestasi atau cidera janji, maka Undang-Undang Hak Tanggungan secara nyata memberikan perlindungan kepada kreditor pemegang Hak Tanggungan, guna mendapatkan pelunasan piutangnya. Banyak cara yang diberikan oleh Undang-Undang Hak Tanggungan apabila si debitor wanprestasi atau cidera janji.

Apabila berbicara mengenai perlindungan hukum bagi kreditor, maka terdapat dua bentuk perlindungan yang dapat diperoleh kreditor. Bentuk perlindungan hukum yang pertama adalah perlindungan hukum secara preventif. Secara garis besar dapat dijelaskan bahwa bentuk perlindungan ini mencoba melindungi kreditor sebelum terjadinya suatu hal-hal ataupun tindakantindakan yang dilakukan oleh debitor dalam upaya pemenuhan prestasinya. Perlindungan hukum secara preventif muncul ketika lahirnya hak kebendaan pada kreditor pemegang Hak Tanggungan atas Obyek Hak Tanggungan yang dijaminkan oleh debitor pemberi Hak Tanggungan. Hak kebendaan tersebut lahir ketika perjanjian atau Akta 
Pembebanan Hak Tanggungan (APHT) beserta sertifikat tanah yang menjadi obyek Hak Tanggungan tersebut didaftarkan pada Kantor Pertanahan. Dalam Pasal 13 ayat (1) jo. penjelasan Pasal 13 ayat (1) UUHT menyatakan bahwa salah satu asas dari Hak Tanggungan adalah publisitas, oleh karenanya harus dilakukan pendaftaran di Kantor Pertanahan. Syarat bahwa akta pembebanan Hak Tanggungan tersebut harus didaftarkan adalah syarat mutlak untuk lahirnya Hak Tanggungan tersebut.

Perlindungan hukum secara preventif lahir ketika lahirnya hak kebendaan pada kreditor pemegang Hak Tanggungan atas Obyek Hak Tanggungan, akan tetapi hak kebendaan tersebut baru lahir ketika para pihak mendaftarkan akta Hak Tanggungan yang telah dibuat oleh para pihak dihadapan Pejabat Pembuat Akta Tanah (untuk selanjutnya disingkat PPAT) pada Kantor Pertanahan, maka dengan demikian dapat disebutkan bahwa lahirnya perlindungan hukum secara preventif kepada kreditor pemegang Hak Tanggungan adalah sejak para pihak mendaftarkan akta Hak Tanggungan pada Kantor Pertanahan.

Bentuk perlindungan hukum yang kedua adalah perlindungan hukum secara represif. Perlindungan hukum secara represif ini baru muncul ketika debitor pemberi Hak Tanggungan wanprestasi atau cedera janji dengan tidak melaksanakan prestasinya sesuai dengan perjanjian kredit yang disepakati. Undang-Undang memberikan jalan kepada kreditor pemegang Hak Tanggungan untuk melakukan eksekusi terhadap Obyek Hak Tanggungan yang dijadikan sebuah jaminan dalam perjanjian hutang-piutang atau perjanjian pemberian kredit tersebut. Dalam Undang-Undang Hak Tanggungan ada berbagai macam cara yang diberikan kepada kreditor pemegang Hak Tanggungan untuk melakukan eksekusi terhadap Obyek Hak Tanggungan. Landasan hukum yang digunakan untuk melakukan eksekusi Hak Tanggungan didalam UndangUndang Hak Tanggungan adalah Pasal 20 UUHT.

Didalam ketentuan Pasal 20 UUHT menyebutkan bahwa :

(1) Apabila debitor cidera janji, maka berdasarkan:

a. Hak pemegang Hak Tanggungan pertama untuk menjual obyek Hak Tanggungan sebagaimana dimaksud dalam Pasal 6, atau

b. Titel eksekutorial yang terdapat dalam sertipikat Hak Tanggungan sebagaimana dimaksud Pasal 14 ayat (2).

Obyek Hak Tanggungan dijual melalui pelelangan umum menurut tata cara yang ditentukan dalam peraturan perundang-undangan untuk pelunasan piutang pemegang Hak Tanggungan dengan hak mendahulu daripada kreditor-kreditor lainnya.

(2) Atas kesepakatan pemberi dan pemegang Hak Tanggungan, penjualan obyek Hak Tanggungan dapat dilaksanakan dibawah tangan jika demikian itu akan dapat diperoleh harga tertinggi yang menguntungkan semua pihak. 
(3) Pelaksanaan penjualan sebagaimana dimaksud pada ayat (2) hanya dapat dilakukan setelah lewat 1 (satu) bulan yang diberitahukan secara tertulis oleh pemberi dan/atau pemegang Hak Tanggungan kepada pihak-pihak yang berkepentingan dan diumumkan sedikit-dikitnya dalam 2 (dua) surat kabar yang beredar didaerah yang bersangkutan dan/atau media massa setempat, serta tidak ada pihak yang menyatakan keberatan.

(4) Setiap janji untuk melaksanakan eksekusi Hak Tanggungan dengan cara yang bertentangan dengan ketentuan pada ayat (1), ayat (2), dan ayat (3) batal demi hukum.

(5) Sampai saat pengumuman untuk lelang dikeluarkan, penjualan sebagaimana dimaksud pada ayat (1) dapat dihindarkan dengan pelunasan utang yang dijamin dengan Hak Tanggungan itu beserta biaya-biaya eksekusi yang dikeluarkan.

Dengan melihat ketentuan diatas, maka ada berbagai macam cara yang bisa ditempuh oleh kreditor pemegang Hak Tanggungan untuk melakukan eksekusi terhadap Obyek Hak Tanggungan guna mendapatkan pelunasan piutangnya.

Salah satu cara yang diberikan kepada kreditor pemengang Hak Tanggungan adalah eksekusi yang didasarkan pada Pasal 6 UUHT yakni menggunakan cara parate executie. Apabila seorang debitor pemberi Hak Tanggungan melakukan wanprestasi atau cidera janji, maka sesuai dengan ketentuan Pasal 6 UUHT, kreditor pemegang Hak Tanggungan pertama mempunyai hak untuk menjual obyek Hak Tanggungan atas kekuasaan sendiri. Disini pembuat Undang-Undang bermaksud untuk mempermudah bagi kreditor pemegang Hak Tanggungan untuk mendapatkan pelunasan atas piutangnya.

Dalam cara tersebut diperbolehkan bagi kreditor untuk menjual obyek Hak Tanggungan atas kekuasaan sendiriatau lebih dikenal dengan istilah parate executi. Dalam parate executie tidak perlu diperjanjikan kembali, karena parate executie muncul secara otomatis atau dengan sendirinya setelah perjanjian hutang piutang disertai dengan jaminan Obyek Hak Tanggungan dibuat oleh para pihak. Dengan kata lain bahwa ketentuan mengenai parate executie ini tidak perlu diperjanjikan kembali.

Dalam penjelasan Pasal 6 UUHT yang mencoba mendiskripsikan atau memberikan pengertian atas pasal tersebut justru menimbulkan kerancuan, karena dalam penjelasan Pasal6UUHT mengatakan bahwa pelaksanaan parate executie atau apabila kreditor pemegang Hak Tanggungan akan melaksanakan eksekusi yang didasarkan pada parate executie sesuai dengan Pasal 6 UUHT, harus diperjanjikan terlebih dahulu antara para kreditor pemegang Hak Tanggungan dengan debitor pemberi Hak Tanggungan.

Namun dalam pelaksanaannya, jika kreditor hanya mengacu pada Pasal 6 UUHT yang mengatakan kreditor pemegang Hak Tanggungan mempunyai hak untuk menjual 
obyek Hak Tanggungan atas kekuasaan sendiri atau parate executie dan menjualnya melalui pelelangan umum sesuai dengan yang diatur dalam Pasal 6 UUHT, hal tersebut tidaklah semudah yang dibayangkan sebelumnya. Dalam mengimplementasikan ketentuan pasal tersebutbiasanyajustruharus diperjanjikan kembali jika debitor pemberi Hak Tanggungan melakukan wanprestasi atau cidera janji, maka kreditor pemegang Hak Tanggungan berhak melakukan parate executie sesuai Pasal 6 UUHT guna mendapatkan pelunasan piutangnya.

Pada dasarnya ketentuan mengenai parate executie bertujuan untuk mempermudah kreditor melakukan eksekusi pada obyek Hak Tanggungan apabila debitor cidera janji. Hal ini dianggap sebagai salah satu jalan mempermudah bagi kreditor pemegang Hak Tanggungan untuk mengeksekusi Obyek Hak Tanggungan karena langsung dapat menjual obyek Hak Tanggungan melalui pelelangan umum dan tidak perlu menunggu fiat dari Ketua Pengadilan Negeri didaerah Obyek Hak Tanggungan berada.

Apabila melalui fiat Ketua Pengadilan Negeri, maka akan memakan waktu yang lama dan biaya yang harus dikeluarkan oleh kreditor pemegang Hak Tanggungan juga semakin banyak. Oleh karenanya pembuat Undang-Undang mengatur mengenai ketentuan menjual obyek Hak Tanggungan atas kekuasaan sendiri (parate executie), sehingga kreditor bisa langsung menjual obyek Hak Tanggungan melalui pelelangan umum tanpa harus meunggu fiat dari Ketua Pengadilan Negeri setempat.
Hal tersebut lebih mendapatkan kepastian hukum dan kemudahan bagi kreditor untuk mendapatkan pelunasan atas piutangnya, sehingga menjamin kembalinya aset dari kreditor pemegang Hak Tanggungan.

Melihat ketentuan tersebut betapa kemudahan yang diberikan kepada kreditor pemegang Hak Tanggungan untuk mendapatkan kembali asetnya sebagai pengembalian piutang dari debitor pemberi Hak Tanggungan, maka dapat dikatakan Pasal 6 UUHT yang mengatur parate executie sebagai salah satu bentuk perlindungan teradap aset dari kreditor pemegang Hak Tanggungan. Hal tersebut dikarenakan Undang-Undang secara nyata mengatur mengenai pelaksanaan parate executie yakni pada Pasal 6 UUHT, sehingga secara otomatis dan tidak perlu diperjanjikan sebelumnya oleh kreditor pemegang Hak Tanggungan dengan debitor pemberi Hak Tanggungan, kreditor pemegang Hak Tanggungan dapat mengeksekusi obyek Hak Tanggungan melalui pelelangan umum apabila debitor pemberi Hak Tanggungan melakukan wanprestasi atau cidera janji, sehingga kreditor pemegang Hak Tanggungan mendapatkan kepastian atau jaminan langsung dari UUHT mengenai pelunasan piutangnya dari hasil penjualan secara lelang obyek Hak Tanggungan.

Pada dasarnya kedua bentuk perlindungan tersebut, baik yang preventif maupun represif, sama-sama bertujuan untuk memberikan perlindungan kepada kreditor pemegang Hak Tanggungan guna menjamin pengembalian asetnya dari debitor pemberi Hak Tanggungan. Sehingga dalam 
kenyataan di masyarakat, kreditor yang akan memberikan kredit disertai jaminan Hak Tanggungan kepada debitor merasa aman dan yakin bahwa asetnya akan kembali dan tidak akan hilang.

\section{Perlindungan Hukum Bagi Debitor Pemberi Hak Tanggungan}

Pada bahasan sebelumnya telah diulas mengenai bentuk perlindungan hukum terhadap kreditor pemegang Hak Tanggungan, terutama mengenai kepastian kembalinya aset kreditor. Dalam UUHT telah memberikan gambaran yang jelas mengenai perlindungan terhadap kreditor tersebut, akan tetapi lain halnya dengan debitor pemberi Hak Tanggungan.

Dalam hal perlindungan hukum terhadap suatu perjanjian pembebanan Hak Tanggungan serta akibat hukumnya tentu tidak terlepas dari adanya upaya untuk melindungi semua pihak yang terkait. Begitu pula dalam hal debitor pemberi Hak Tanggungan, juga harus diberi porsi yang sama sebagai bentuk perlindungan hukumnya.

Berbicara mengenai perlindungan hukum, sudah pasti ada dua jenis bentuk, yakni preventif dan represif. Sesuai dengan pembahasan sebelumnya, bahwa bentuk perlindungan hukum secara preventif pada dasarnya memberikan perlindungan sebelum terjadinya suatu yang tidak diinginkan atau dengan kata lain perlindungan ini sebagai bentuk pencegahan terjadinya hal-hal yang bisa merugikan para pihak yang saling mengikatkan dalam suatu perjanjian.
Bentuk perlindungan hukum secara preventif ini didapat oleh debitor pemberi Hak Tanggungan sejak pra perjanjian kredit dengan jaminan antara kreditor dengan debitor. Setelah debitor mengajukan proposal permohonan kredit kepada kreditor (dalam hal ini bank) maka proposal tersebut akan diolah dengan mempertimbangkan berbagai hal guna keamanan kredit yang diberikan oleh kreditor. Dalam hal perjanjian kredit tersebut disertai dengan jaminan kebendaan, maka perlu dan wajib diadakan penilaian terhadap jaminan yang akan digunakan dalam menjamin kredit tersebut.

Dalam dunia perbankan Indonesia, ada yang disebut Penyisihan Penghapusan Aktiva atau biasa disebut PPA. Dalam pasal 1 angka (19) Peraturan Bank Indonesia No. 8/2/PBI/2006 tentang perubahan atas Peraturan Bank Indonesia No. 7/2/PBI/2005 tentang Penilaian Aktiva Bank Umum, yang dimaksud dengan PPA adalah cadangan yang harus dibentuk sebesar persentase tertentu berdasarkan kualitas aktiva. Dalam perjanjian kredit, yang digunakan sebagai nilai pengurang dalam pembentukan PPA biasanya berupa agunan yang digunakan sebagai jaminan dalam perjanjian kredit.

Dengan demikian maka agunan yang dijaminkan oleh debitor mempunyai nilai yang kemudian akan digunakan untuk mengurangi nilai PPA yang harus disediakan oleh Bank selaku kreditor pemberi kredit. Nilai agunan tersebut berasal dari penilaian yang dilakukan oleh bank. Dalam penjelasan pasal 48 PBI No. 8/2/PBI/2006 jo. PBI No. 7/2/PBI/2005, penilaian adalah suatu pernyataan tertulis dari penilai independen 
atau penilai intern bank yang berisikan mengenai taksiran dan pendapat atas nilai ekonomis dari agunan berdasarkan analisis terhadap fakta-fakta obyektif dan relevan menurut metode dan prinsip-prinsip yang berlaku umum yang ditetapkan oleh asosiasi dan atau institusi yang berwenang.

Menurut pengaturan tersebut, maka penilaian dapat dilakukan oleh penilai intern bank atau dapat juga dilakukan oleh penilai independen. Mengenai Penilai independen, Bank Indonesia telah mengatur mengenai kriteria penilai independen yang dapat digunakan dalam menilai agunan tersebut. Pasal 38 ayat (7) PBI No. 8/2/PBI/2006 jo. PBI No. 7/2/PBI/2005 mengatur bahwa yang menjadi kriteria suatu perusahaan atau suatu lembaga sebagai penilai independen adalah:

a. Tidak merupakan pihak terkait dengan bank;

b. Tidak merupakan kelompok peminjam dengan debitor bank;

c. Melakukan kegiatan penilaian berdasarkan kode etik profesi dan ketentuan-ketentuan yang ditetapkan oleh institusi yang berwenang;

d. Menggunakan metode penilaian berdasarkan standar profesi penilaian yang diterbitkan oleh institusi yang berwenang;

e. Memiliki izin usaha dari institusi yang berwenang untuk beroperasi sebagai perusahaan penilai;

f. Tercatat sebagai asosiasi yang diakui oleh institusi yang berwenag.

Bank Indonesia dalam hal penilaian atas agunan tersebut mencoba mengatur lebih lanjut mengenai kapan penilaian agunan tersebut dilakukan oleh pihak intern bank dan kapan penilaian tersebut dilakukan oleh penilai independen. Dalam pasal 49 PBI No. 8/2/PBI/2006 tentang Perubahan atas PBI No. 7/2/PBI/2005 tentang Penilaian Aktiva Bank Umum mengatur sebagai berikut:

(1) Dalam hal agunan akan digunakan sebagai pengurang PPA, penilaian agunan wajib dilakukan oleh penilai independen sebagaimana dimaksud dalam Pasal 38 ayat (3) bagi aktiva produktif lebih dari Rp. 5.000.000.000,00 (lima milyar rupiah) kepada debitor atau kelompok peminjam.

(2) Penilaian agunan dapat dilakukan oleh penilai intern Bank, bagi aktiva produktif yang diberikan sampai dengan jumlah Rp. 5.000.000.000,00 (lima milyar rupiah) kepada debitor atau kelompok peminjam.

Dalam pasal 49 ayat (2) tersebut diatas, terdapat kata "dapat", hal ini mempunyai makna bahwa bank dapat menggunakan penilai intern bank dalam melakukan penilaian terhadap agunan atau juga dapat menggunakan penilai independen. Katakata "dapat" sebenarnya memberikan peluang kepada debitor yang nilai kreditnya dibawah Rp. 5.000.000.000,00 (lima milyar rupiah) untuk mengajukan permohonan kepada bank agar dalam melakukan penilaian terhadap agunan dilakukan oleh penilai independen. Hal ini didasarkan pada kata-kata "dapat" yang bermakna alternatif, 
artinya memberikan sebuah pilihan yang lain. Apabila penilaian terhadap agunan dilakukan oleh intern bank dirasa debitor kurang obyektif karena bagaimanapun juga hasil penilaian tersebut mempengaruhi jumlah fasilitas kredit yang akan diberikan bank, maka debitor dapat meminta kepada bank agar penilaian tersebut dilakukan oleh penilai independen.

Dengan demikian pengaturan tersebut pada dasarnya adalah wujud perlindungan hukum secara preventif bagi debitor terhadap asetnya berupa agunan yang dijadikan jaminan dalam perjanjian kredit dengan bank selaku kreditor. Karena dengan adanya penilaian tersebut, debitor dapat jaminan mengenai nilai yang diberikan terhadap agunannya oleh bank selaku kreditor. Tidak bisa dilupakan bahwa besarnya nilai suatu agunan akan sangat berpengaruh terhadap besarnya fasilitas kredit yang akan diperoleh debitor.

Penilaian atas agunan tersebut tidak hanya dilakukan pada awal pembentukan perjanjian kredit saja, tetapi juga dilakukan setelah terbentuknya perjanjian kredit atau ketika berlangsungnya perjanjian kredit tersebut. Dengan demikian maka penilaian tersebut memberikan kepastian terhadap perubahan atas nilai agunan sesuai dengan kondisi ekonimis agunan yang setiap saat bisa berubah. Selain itu juga memberikan informasi kepada kreditor dan debitor atas nilai agunan tersebut sehingga kreditor dan debitor dapat memperkirakan berapa besar nilai jaminannya berkembang sampai pada batasan waktu berakhirnya perjanjian kredit disertai jaminan tersebut.
Selain itu, bentuk perlindungan hukum preventif bagi debitor pemberi Hak Tanggungan juga diberikan oleh UUHT secara nyata dalam pasal 12 UUHT jo. penjelasan. Dimana dalam pasal 12 UUHT berbunyi:

"janji yang memberikan kewenangan kepada pemegang Hak Tanggungan untuk memiliki obyek Hak Tanggungan apabila debitor cidera janji, batal demi hukum"

Dengan ketentuan tersebut, maka si pembuat undang-undang bermaksud untuk melindungi aset debitor pemberi Hak Tanggungan. terlebih lagi jika melihat ketentuan pada penjelasan pasal 12 UUHT, dimana ketentuan tersebut berbunyi:

"ketentuan ini adalah dalam rangka melindungi kepentingan debitor dan pemberi Hak Tanggungan lainnya, terutama jika nilai obyek Hak Tanggungan melebihi besarnya utang yang dijamin. Pemegang Hak Tanggungan dilarang untuk serta merta memiliki obyek Hak Tanggungan karena debitor cidera janji. Walaupun demikian tidaklah dilarang bagi pemegang Hak Tanggungan untuk menjadi pembeli obyek Hak Tanggungan asalkan melalui prosedur yang diatur dalam pasal 20"

Dengan demikian maka secara nyata UUHT telah memberikan perlindungan hukumbagidebitorpemberiHakTanggungan untuk merasa aman menjaminkan asetnya dan membebaninya dengan Hak Tanggungan. pengaturan tersebut bermaksud meminimalisir kecurangan yang dilakukan kreditor pemegang Hak Tanggungan, melihat kemudahan-kemudahan yang diberikan 
oleh UUHT kepada kreditor pemegang Hak Tanggungan untuk mengeksekusi obyek Hak Tanggungan dengan cara parate executie apabila debitor pemberi Hak Tanggungan cidera jenji.

Selain itu juga pengaturan tersebut bertujuan untuk melindungi nilai aset debitor yang dijadikan obyek Hak Tanggungan, hal tersebut berkaitan karena biasanya nilai obyek jaminan lebih besar daripada nilai utang debitor pemberi Hak Tanggungan kepada kreditor pemegang Hak Tanggungan.

Perlindungan hukum yang kedua adalah perlindungan hukum secara represif. Hal tersebut lebih mendasarkan pada apabila hal yang tidak diinginkan telah terjadi, artinya debitor telah melakukan cidera janji atau wanprestasi, maka perlindungan represif ini diberikan kepada debitor pemberi Hak Tanggungan agar Obyek Hak Tanggungan dapat dilelang menggunakan lembaga parate executie dengan harga yang paling tinggi.

Dalam pembahasan sebelumnya telah dibahas mengenai tata cara pelaksanaan eksekusi terhadap obyek Hak Tanggungan yang didasarkan pada Pasal 6 UUHT, yakni menggunakan cara parate executie. Dalam hal pelaksanaan parate executie yang didasarkan pada pasal 6 UUHT, meskipun tanpa melalui fiat pengadilan namun tetap harus melalui lembaga balai lelang negara. Pada pasal 20 ayat (1) UUHT dijelaskan bahwa eksekusi obyek Hak Tanggungan yang didasarkan pada pasal 6 UUHT dijual melalui pelelangan umum.
Selain pada pasal 20 ayat (1) UUHT, pengaturan tersebut juga diatur dalam Keputusan Menteri Keuangan Republik Indonesia No. 339/KMK.01/2000 tentang balai lelang, mengatur bahwa kegiatan usaha balai lelang selain lelang sukarela juga meliputi parate executie Hak Tanggungan, fidusia dan barang-barang yang tidak dimiliki atau dikuasai oleh negara.

Apabila melalui balai lelang, tentu harus ada aturan mengenai pelaksanaan lelang, agar tidak merugikan kreditor selaku pemegang Hak Tanggungan dan debitor selaku pemberi Hak Tanggungan. apabila kredtor akan melakukan eksekusi atas Obyek Hak Tanggungan ketika debitor dianggap telah lalai atau cidera janji sehingga tidak dapat memenuhi kewajibannya, maka kreditor harus mengajukan permohonan lelang kepada kepala balai lelang, tetapi sebelum melakukan lelang, terlebih dahulu balai lelang memberitahukan adanya surat permohonan lelang dari kreditor, kepada debitor. Hal ini dimaksudkan agar debitor mengetahui bahwa pihak kreditor pemegang Hak Tanggungan telah mendaftarkan Obyek Hak Tanggungan untuk dilelang melalui balai lelang karena debitor dianggap cidera janji dan dianggap tidak dapat memenuhi kewajibannya.

Mengenai pelelangan tersebut, sebelum dilakukannya pelelangan atas Obyek Hak Tanggungan, maka terlebih dahulu akan diumumkan selama 2 (dua) kali berturutturut dalam surat kabar yang terbit dikota dimana Obyek Hak Tanggungan berada dan tempat domisili yang ditunjuk dalam perjanjian kredit tersebut. Pengumuman 
tersebut dilakukan dengan tenggang waktu 15 (limabelas) hariantarapengumuman yang pertama dengan pengumuman yang kedua. Hal tersebut seperti yang diatur dalam pasal 20 ayat (3) jo. penjelasan UUHT. Hal inilah sebenarnya yang dimaksudkan perlindungan hukum secara represif terhadap aset debitor. Pengumuman ini dimaksud selain untuk memberitahukan adanya upaya lelang oleh kreditor pemegang Hak Tanggungan pertama kepada kreditor pemegang Hak Tanggungan kedua; ketiga; dan kreditor lain, juga bertujuan untuk melindungi debitor agar aset debitor menjadi terjamin karena pemberitahuan lelang tersebut sebenarnya juga bertujuan untuk membuka harga penawaran yang wajar kepada pihak ketiga yang akan membeli Obyek Hak Tanggunan tersebut.

Dengan demikian maka secara tidak langsung pemberitahuan di 2 (dua) media masa berbeda memberikan keuntungan bagi debitor sebagai ajang promosi atas Obyek Hak Tanggungan yang akan dilelang. Perlindungan hukum secara represif tidak hanya terkait dengan pengumuman lelang oleh balai lelang sebelum pelaksanaan lelang, tetapi juga menyangkut sifat lelang yang akan dilaksanakan. Pelaksanaan lelang oleh balai lelang sebagai wujud eksekusi atas Obyek Hak Tanggungan yang didasarkan atas parate executie bersifat terbuka. Artinya pelelangan oleh balai lelang bersifat terbuka, termasuk dalam hal penentuan harga limit lelang.

Salah satu asas dalam pelelangan adalah asas obyektifitas, artinya lelang tersebut bersifat terbuka untuk umum dipimpin oleh pejabat Kantor Pengurusan Piutang dan Lelang Negara (KP2LN) yang independen untuk kepentingan semua pihak terutama untuk melindungi kepentingan debitor, kreditor, dan pemenang lelang ${ }^{29}$.

Dengan demikian lelang tersebut bersifat terbuka, termasuk penentuan harga awal lelang dan penentuan harga limit lelang. Dalam melakukan lelang, balai lelang telah menentukan batasan-batasan harga atas Obyek Lelang yang dibiritahukan kepada kreditor dan debitor. Dengan demikian debitor akan merasa aman bahwa asetnya yang dijaminkan dan dibebani Hak Tanggungan tidak akan dihargai dibawah harga yang wajar dipasaran.

Selain itu pelelangan yang bersifat terbuka juga memberikan kesempatan kepada semua pihak tidak terkecuali untuk dapat mengikuti proses pelelangan, yang tentu saja semakin banyak yang ikut dalam proses lelang, maka akan berdampak pada persaingan harga untuk mencapai harga tertinggi atas Objek Lelang. Hal tersebut tercipta dari kondisi persaingan para peserta lelang dalam proses pelelangan untuk dapat membeli Obyek Lelang.

Perlindungan secara represif terhadap aset debitor pemberi Hak Tanggungan juga terjadi atas penentuan harga lelang. Dalam hal penentuan harga lelang, terlebih dahulu balai lelang akan mengadakan musyawarah dengan kreditor dan debitor untuk menentukan penetapan harga limit lelang, sehingga tidak merugikan salah satu pihak.

${ }^{29}$ I Made Soewandi, Balai Lelang Kewenangan Balai Lelang Dalam Penjualan Jaminan Kredit Macet, Yayasan Gloria, Yogyakarta, hal. 68. 
Dalam hal penentuan harga limit lelang biasanya dibagi menjadi tiga bagian, yang pertama harga tertinggi atas Obyek Lelang. Harga ini mengacu pada harga yang ada di pasaran. Dengan harga ini mungkin akan didapatkan harga jual tertinggi atas Obyek Lelang, sehingga dapat memuaskan debitor pemberi Hak Tanggungan selaku pemegang Hak Kebendaan.

Harga limit lelang yang kedua adalah harga sesuai dengan Nilai Jual Obyek Pajak, harga ini ditentukan oleh Badan Pertanahan Nasional. Apabila dengan menggunakan Harga Limit lelang yang pertama tidak berjalan sesuai dengan keinginan, maka penentuan harga diubah menjadi harga limit lelang yang didasarkan pada Nilai Jual Obyek Pajak.

Apabila menggunakan harga limit lelang yang kedua juga tidak maksimal maka akan menggunakan harga limit lelang yang ketiga, yaitu harga lelang yang didasarkan pada nilai kredit yang diberikan oleh kreditor kepada debitor ditambah dengan biayabiaya lelang. Cara ini merupakan alternatif terakhir dalam hal penentuan harga limit lelang.

Apabila nantinya didapatkan harga lelang yang wajar dan dinilai cukup bagi para pihak, maka dari harga tersebut setelah dikurangi biaya-biaya lelang, maka harus dibayarkan kepada kreditor hanya sebatas tunggakan sekaligus pelunasan hutang debitor, sisanya akan dikembalikan kepada debitor.

Hal inilah yang disebut sebagai perlindungan hukum represif bagi aset debitor, agar debitor tidak merasa dirugikan, karena eksekusi yang dilakukan kreditor bukan semata-mata karena debitor cidera janji maka kreditor dapat seenaknya menjual Onyek Hak Tanggungan, tetapi ada beberapa syarat yang harus dipenuhi sebagai wujud perlindungan aset debitor. Telah menjadi rahasia umum bila harga tanah dan bangunan setiap tahunnya mengalami perubahan atas harga jual tentu saja selalu mengalami kenaikan harga. Jangan sampai dengan kenaikan harga tersebut, debitor masih terpaku pada harga lama ketika awal membentukperjanjian kreditdengan kreditor disertai dengan jaminan kebendaan.

Harga jual yang lebih besar inilah yang menjadi hak dari debitor dan wajib untuk dilindungi karena merupakan aset dari debitor pemberi Hak Tanggungan atas Obyek Jaminan.

\section{Kesimpulan}

Dalam hal kewenangan kreditor selaku pemegang Hak Tanggungan dalam melakukan eksekusi dengan cara Parate Executie, UUUHT memberikan kewenangan tersebut kepada kreditor. Sekalipun sampai saat ini masih menjadi sebuah perdebatan yang panjang diantara ahli-ahli hukum di Indonesia mengenai harus diperjanjikan terlebih dahulu atau tidak harus diperjanjikan mengenai eksekusi dengan cara Parate Executie. Kreditor pemegang Hak Tanggungan dapat melakukan eksekusi dengan cara Parate Executie apabila debitor pemberi Hak Tanggungan melakukan wanprestasi atau cidera janji. Melalui Pasal 6 UUHT jo. Pasal 20 UUHT kreditor 
pemegang Hak Tanggungan mendapat perlindungan atas asetnya dari UndangUndang Hak Tanggungan (UUHT).

Dalam UUHT ternyata tidak hanya memberikan perlindungan hukum bagi kreditor pemegang Hak Tanggungan saja tetapi juga memberikan perlindungan hukum bagi debitor pemberi Hak Tanggungan, sekalipun UUHT hanya menitik beratkan perlindungan debitor tersebut pada besaran nilai ekonomis obyek Hak Tanggungan, namun hal tersebut telah memberikan rasa aman bagi debitor pemberi Hak Tanggungan untuk menjaminkan asetnya dan dibebani Hak Tanggungan. UUHT memberikan perlindungan hukum kepada debitor pemberi Hak Tanggungan apabila dikemudian hari debitor cidera janji, maka dalam pelaksanaan eksekusi melalui Parate Executie debitor tidak dirugikan dalam hal penilaian atas harga jual Obyek Hak Tanggungan, dengan demikian debitor pemberi Hak Tanggungan berhak untuk mendapatkan harga tertinggi dalam lelang Obyek Hak Tanggungan.

Dalam melakukan eksekusi terhadap Obyek Hak Tanggungan, ternyata tidak hanya menggunakan Parate Executie. Pasal 20 UUHT mengatur mengenai eksekusi terhadap Obyek Hak Tanggungan dapat dilakukan dengan cara Parate Executie, Titel Eksekutorial, penjualan dibawah tangan. Dalam pelaksanaan eksekusi Obyek Hak Tanggungan sebaiknya melalui cara penjualan dibawah tangan, hal tersebut dikarenakan penjualan tersebut tidak melalui lelang seperti Parate Executie dan Titel Eksekutorial, hanya berdasarkan kesepakatan bersama antara kreditor pemegang Hak Tanggungan dengan debitor pemberi Hak Tanggungan. dengan demikian dapat diperoleh harga tertinggi terhadap Obyek Hak Tanggungan. selain itu dengan menggunakan eksekusi dengan cara penjualan dibawah tangan, maka akan lebih mudah, tidak perlu mengeluarkan biaya tambahan untuk pelelangan, dan tidak membutuhkan waktu yang terlalu lama karena tidak perlu menunggu fiat dari ketua pengadilan negeri. Hal tersebut berbeda apabila menggunakan cara Titel Eksekutorial yang harus ada fiat dari ketua pengadilan negeri dan Parate Executie yang harus melalui lembaga lelang.

Dalam UUHT tidak mengatur secara terperinci dan detail mengenai perlindungan hukum bagi debitor pemberi Hak Tanggungan. sebaiknya kedepan UUHT dapat disempurnakan dan memasukkan pengaturan yang lebih jelas mengenai perlindungan hukum debitor pemberi Hak Tanggungan dan memberikan porsi yang sama dan adil dengan pengaturan perlindungan hukum kreditor pemegang Hak Tanggungan.

\section{DAFTAR BACAAN}

\section{Buku}

Badrulzaman, Mariam Darus, Kompilasi Hukum Jaminan Buku II, Mandar Maju, Bandung, 2004.

Poesoko, Herowati, Parate Executie Obyek Hak Tanggungan (Inkonsistensi, Konflik Norma dan Kesesatan Penalaran dalam UUHT, LaksBang PRESindo, Yogyakarta, 2007. 
Satrio, J., Hukum Jaminan Hak Jaminan

Kebendaan, Citra Aditya Bakti, Bandung, 2007. , Hukum Jaminan, Hak-Hak Kebendaan, Citra Aditya Bakti, Bandung, 1986.

Sjahdeni, Sutan Remy, Hak Tanggunan Asas-Asas, Ketentuan Pokok, dan Masalah yang Dihadapi Oleh Perbankan, Alumni, Bandung, 1999.

Soewandi, I Made, Balai Lelang, Kewenangan Balai Lelang dalam Penjualan Jaminan Kredit Macet, Yayasan Gloria, Yogyakarta, 2007.

Soesilo, R., Herzein Inlandsch Reglement, RIB/HIR, Politea, Bogor, 1985.

Sofwan, Sri Soedewi Masjchoen, Hukum Jaminan di Indonesia, PokokPokok Hukum Jaminan dan Jaminan Perorangan, Liberty Offset, Yogyakarta, 1980.

Tjitrosudibio, Subekti R., Kitab UndangUndang Hukum Perdata, Burgerlijk Wetboek, cetakan ke-28, Pradnya Paramita, Jakarta, 1996

\section{Peraturan Perundang-Undangan}

Undang-Undang No. 4 Tahun 1996 Tentang Hak Tanggungan atas Tanah dan Benda-Benda yang Berkaitan Dengan Tanah.

Undang-Undang No. 10 Tahun 2004 Tentang Pembentukan Peraturan PerundangUndangan.

Undang-Undang No. 7 Tahun 1992 tentang Perbankan.

Undang-Undang No. 10 Tahun 1998 tentang Perubahan Atas Undang-Undang No. 7 Tahun 1992 Tentang Perbankan.

Peraturan Bank Indonesia No. 7/2/PBI/2005 Tentang Penilaian Kualitas Aktiva Bank Umum.

Peraturan Bank Indonesia No. 8/2/PBI/2006 Tentang Perubahan Atas Peraturan Bank Indonesia No. 7/2/PBI/2005 Tentang Penilaian Kualitas Aktiva Bank Umum.

\section{$\underline{\text { Artikel }}$}

Isnaeni, M., Kerancuan Hak Tanggungan Dalam Kaitannya Sebagai Pengaman Penyaluran Kredit Bank, AMRTA, Vol. 1, No. 1, Mei 1999. 